DANUTA JANCZEWSKA

Społeczna Akademia Nauk w Łodzi, Polska - University of Social Sciences in Łódź, Poland

\title{
Proces zarządzania zasobami wiedzy w działalności logistycznej przedsiębiorstw MŚP
}

\section{Process of Knowledge Management in Logistics Activity in SMEs}

Streszczenie: Proces zarządzania zasobami wiedzy w aspekcie działalności logistycznej przedsiębiorstw z sektora MŚP jest prezentowany stosunkowo rzadko w literaturze przedmiotu. Opisy zarządzania wiedzą w procesach logistycznych w przedsiębiorstwach opierają się w głównej mierze na modelach odnoszących się do dużych przedsiębiorstw. Modele zarządzania dużymi przedsiębiorstwami z kolei opierają się na rozbudowanej strukturze organizacyjnej oraz zdefiniowanych wzajemnie powiązanych procesach. Zasoby wiedzy w dużych przedsiębiorstwach składają się z wiedzy ukrytej oraz jawnej, przy czym występuje zjawisko konwersji jednej kategorii wiedzy w drugą. W literaturze przedmiotu brak jest analiz dotyczących istotnych różnic w zarządzaniu zasobami wiedzy w działalności logistycznej pomiędzy dużymi firmami a małymi i średnimi przedsiębiorstwami. Celem niniejszego artykułu jest prezentacja badań własnych dotyczących procesu zarządzania wiedzą w działalności logistycznej w sektorze MŚP. W pracy sformułowano problemy badawcze, które zostały przeanalizowane na podstawie badań prowadzonych w latach 2015-2016 wśród 50 małych i średnich przedsiębiorstw Z województwa kujawsko-pomorskiego, łódzkiego oraz mazowieckiego. W artykule przedstawiono wyniki badania typu case study. Na podstawie wyników badań sformułowano założenia do modelu zarządzania wiedzą w działalności logistycznej w badanych przedsiębiorstwach.

Abstract: Process of Knowledge Management (KM) in logistic activity of SMEs is presented not so often in literature of the subject. Description of knowledge management in SMEs are mostly based on models appropriate for big enterprises. Models of management of big enterprise in turn are based on elaborate organisational structure and defined interlinked processes. Knowledge resources in big enterprises are composed of hidden knowledge and open knowledge and there is the phenomena of conversion of one category into another. There is a lack of description of differences between Knowledge Management $(\mathrm{KM})$ in big enterprises and SMEs. The goal of the article is to present the results of own research. Discussed are the results of studies conducted in Kujawsko-Pomorskie, Łódzkie, and Mazowieckie voivodeship on knowledge management process in logistics activity in SMEs in 2010-2016. The article analyses the results of case study research from 50 SMEs. The following methods were used: questionnaire survey, interview, discussion with experts, case study method. Based on research results, assumptions for a model of knowledge management in logistic activities of studied SMEs were made. 
Słowa kluczowe: MŚP; organizacja ucząca się; system logistyczny; wiedza; zarządzanie wiedzą

Keywords: knowledge management; learning organisation; logistics system; SMEs

Otrzymano: 28 października 2017

Received: 28 October 2017

Zaakceptowano: 27 maja 2018

Accepted: 27 May 2018

Sugerowana cytacja/Suggested citation:

Janczewska, D. (2018). Proces zarządzania zasobami wiedzy w działalności logistycznej przedsiębiorstw MŚP. Przedsiębiorczość - Edukacja [Entrepreneurship - Education], 14, 177-187. DOI: $10.24917 / 20833296.14 .13$

\section{Wstęp}

Proces zarządzania zasobami wiedzy w przedsiębiorstwie jest obiektem zainteresowania wielu badaczy. Interpretacja zarządzania zasobem niematerialnym, jakim jest wiedza, wymaga objaśnienia użyteczności oraz wartości wiedzy. Współczesne przedsiębiorstwo buduje swój system logistyczny na podstawie posiadanych zasobów oraz w sposób zapewniający spełnienie oczekiwań klientów. Elementami systemu logistycznego są procesy, których celem ostatecznym jest osiąganie wymaganych przez klientów cech produktu lub usługi. Wiedza jest niezbędna do przygotowania tychże procesów, zarządzania nimi, kontrolowania ich oraz ustalania ich miar efektywności. Na tej podstawie sformułowano dwa problemy badawcze:

- P1: Proces zarządzania zasobami wiedzy w działalności logistycznej w przedsiębiorstwie MŚP może być definiowany na podstawie modelu spirali wiedzy (model japoński).

- P2: Działalność logistyczna małej i średniej firmy jest uwarunkowana zarządzaniem zasobami wiedzy w ujęciu procesowym.

W artykule przedstawiono badania własne autorki nad istotą zarządzania wiedzą w realizacji procesów logistycznych oraz wyniki badania typu case study na przykładzie przedsiębiorstwa cukierniczego.

\section{Zasoby wiedzy w organizacji w świetle koncepcji GOW}

Termin „zarządzanie wiedzą” został po raz pierwszy sformułowany przez P. Tomscany’ego w roku 1966 w aspekcie zarządzania wiedzą w pracy badawczej nad teorią gier (Gierszewska, 2011). Za początek zainteresowania zarządzaniem wiedzą jako problemem naukowym uznaje się konferencję „Managing the Knowledge Assets into 21st Century” zorganizowaną w roku 1987 w USA (Strojny, 2000). Znaczenie wiedzy jako zasobu znajduje odniesienie w koncepcjach zasobowych rozwoju wzrostu przedsiębiorstwa (Teece, 1998). Znaczenie wiedzy dla rozwoju gospodarczego jako pierwszy dostrzegł Drucker (Drucker, 1999). Porter zdefiniował trzy stadia rozwojowe zarządzania wiedzą: czynniki produkcji, inwestycje oraz innowacje (Porter, 1990), uznając, iż najważniejszym czynnikiem są innowacje oparte na wiedzy. Tofflerowie określili wiedzę jako „uniwersalny substytut, kluczowy zasób rozwiniętej gospodarki” (Toffler A., Toffler H., 1999: 17). Strojny zdefiniował istotne elementy różnicujące pomiędzy erą przemysłową a erą wiedzy (Strojny, 2000). Zdaniem Strojnego największy wpływ na budowanie zasobów wiedzy ma 
dynamiczny rozwój technik informacyjnych oraz informatyki i elektroniki. Baruk podaje, iż przedsiębiorstwo powinno zapewniać warunki do rozwoju wiedzy i kwalifikacji pracowników (Baruk, 2006). Gierszewska z kolei uznaje kluczową rolę wiedzy i formułuje listę głównych czynników wiedzy, do których należą (Gierszewska, 2011):

- traktowanie wiedzy jako zasobu,

- szybki (wykładniczy) przyrost nowej wiedzy oraz błyskawiczne rozprzestrzenianie,

- złożoność wiedzy, trudność jej przyswojenia i przekazania innym,

- wzrost złożoności produktów,

- zmiana tradycyjnych metod zarządzania.

Wojnicka przedstawia znaczącą rolę zarządzania wiedzą w rozwoju innowacji w sektorze MŚP (Wojnicka, 2011), co zaznacza się współcześnie w strukturach wirtualnych oraz w e-biznesie. W procesie zarządzania wiedzą pojawia się konieczność dzielenia się wiedzą oraz wdrażania rozwiązań innowacyjnych opartych na wiedzy we wszystkich obszarach działalności organizacji, których zakres wynika ze strategii edukacyjnej przedsiębiorstwa ${ }^{1}$. Efekty zarządzania wiedzą to: zwiększenie innowacyjności, doskonalenie zarządzania przedsiębiorstwem, optymalizacja zasobów materialnych i niematerialnych. Na gruncie rozwoju koncepcji zarządzania wiedzą powstały uzupełniające pojęcia, w tym pojęcie organizacji uczącej się. Do cech takiej organizacji należy zaliczyć:

- nastawienie na przyszłość,

- doskonalenie, które ma charakter ciągły,

- definiowanie i poszukiwanie nowych możliwości rozwoju,

- proaktywny stosunek do ryzyka,

- traktowanie otoczenia jako możliwości poszukiwania szans rozwoju.

Pojęcie organizacji uczącej się może być uzupełnione pojęciem organizacji inteligentnej. Koncepcja tego drugiego pojęcia powstała w USA, Szwajcarii, Niemczech i Francji i stanowi rodzaj objaśnienia dotyczącego organizacji doskonalącej się i posiadającej umiejętności uczenia się. Zgodnie z definicją organizacji inteligentnej, której autorami są Nonaka i Takeuchi: „Inteligentna organizacja nie jest oparta o wyspecjalizowane działy badawczo-rozwojowe, ale o sposób zachowania członków organizacji i kulturę organizacyjną, w ramach której każdy jest pracownikiem wiedzy, przedsiębiorcą" (Nonaka, Takeuchi, 1995: 23). Za propagatora idei organizacji uczących się uważany jest Senge (Senge, 2012)2.

Przyjmuje się, że każda organizacja ma określony poziom inteligencji, pozwalający na dostosowanie się tej organizacji do otoczenia, ułatwiający jej członkom proces uczenia się i podlegający ciągłym transformacjom. Składowymi systemu zarządzania wiedzą są (Błaszczuk, 2004):

- pozyskiwanie wiedzy,

- selekcja wiedzy,

- przetwarzanie i adaptacja wiedzy dla potrzeb przedsiębiorstwa,

- kodyfikacja wiedzy,

\footnotetext{
${ }^{1}$ Przykładem takiej działalności edukacyjnej jest Grupa Tubądzin TMG Sp. z o.o. Od 01.08.2010 r. spółka ta rozpoczęła realizację projektu „Rozwój kadr Tubądzin management Group Sp. z o.o.”, współfinansowanego przez Unię Europejską ze środków EFS w ramach Programu Operacyjnego Kapitał Ludzki. Celem projektu jest wspieranie rozwoju pracowników i przedsiębiorstwa w regionie. Projekt zakłada przeprowadzenie kompleksowego programu szkoleń ogólnych, rozwijających kompetencje kluczowe pracowników TMG. Zob. http://www. tubadzin.pl/projekty-efs

${ }^{2}$ Koncepcję organizacji uczącej się przedstawił P. Senge (2012).
} 
- transfer wiedzy,

- kreowanie nowej wiedzy,

- dzielenie się wiedzą,

- aktualizacja bazy wiedzy.

Model japoński zarządzania wiedzą jest efektem badań Nonaki i Takeuchiego, którzy na początku lat 90. opracowali model „spirali wiedzy”. Wyróżnili oni cztery procesy powtarzające się w określonej sekwencji procesów konwersji wiedzy. Są to: socjalizacja, czyli zamiana wiedzy cichej (ukrytej) w wiedzę cichą (ukrytą), eksternalizacja, czyli zamiana wiedzy cichej (ukrytej) w wiedzę formalną (dostępną), kombinacja, czyli zamiana wiedzy formalnej (dostępnej) w wiedzę formalną (dostępną), internalizacja, czyli zamiana wiedzy formalnej (dostępnej) w wiedzę cichą (ukrytą). Podstawą powyższej koncepcji zarządzania wiedzą jest wyróżnienie dwóch kategorii wiedzy: wiedzy jawnej i wiedzy ukrytej (cichej).

Spośród wielu współczesnych modeli zarządzania wiedzą najbardziej znany jest model zasobowy, łączący kluczowe umiejętności przedsiębiorstwa z elementami otoczenia w określonym horyzoncie czasowym. Pozostałe modele opierające się na rozwiązaniach i doświadczeniach praktycznych dużych firm konsultingowych łączy podejście procesowe (Sopińska, Wachowiak, 2006). Cztery podstawowe strategie zarządzania wiedzą stosowane w różnych sektorach i branżach przedstawiono w tabeli 1.

Tab. 1. Strategia zarządzania wiedzą w przedsiębiorstwie

\begin{tabular}{|c|c|c|c|}
\hline Lp. & $\begin{array}{c}\text { Podejście do zarządzania } \\
\text { wiedzą }\end{array}$ & Cel strategii & $\begin{array}{l}\text { Podejście do kapitału } \\
\text { intelektualnego }\end{array}$ \\
\hline I & $\begin{array}{l}\text { Zarządzanie wiedzą jest } \\
\text { kluczowym aktywem } \\
\text { przedsiębiorstwa }\end{array}$ & $\begin{array}{l}\text { Celem tej strategii } \\
\text { zarządzania wiedzą jest jej } \\
\text { ochrona i wykorzystanie do } \\
\text { tworzenia nowych zasobów } \\
\text { intelektualnych }\end{array}$ & $\begin{array}{l}\text { Funkcjonowanie } \\
\text { przedsiębiorstw jest } \\
\text { zdeterminowane przez } \\
\text { poziom zdolności } \\
\text { intelektualnych posiadanych } \\
\text { przez pracowników, a nie } \\
\text { przez zasoby materialne }\end{array}$ \\
\hline II & $\begin{array}{l}\text { Zarządzanie wiedzą } \\
\text { traktowane jest jako sposób } \\
\text { na doskonalenie produktów } \\
\text { i usług }\end{array}$ & $\begin{array}{l}\text { Doskonalenie aktywów } \\
\text { przedsiębiorstwa } \\
\text { rozumianych jako zasoby } \\
\text { fizyczne }\end{array}$ & $\begin{array}{l}\text { Kapitał intelektualny } \\
\text { służy jedynie ulepszeniu } \\
\text { i unowocześnieniu } \\
\text { produktów, poprawiając } \\
\text { pozycję konkurencyjną }\end{array}$ \\
\hline III & $\begin{array}{l}\text { Zarządzanie wiedzą jest } \\
\text { podstawową działalnością } \\
\text { firmy. Sytuacja taka } \\
\text { występuje w przypadku } \\
\text { firm konsultingowych, } \\
\text { urzędów statystycznych oraz } \\
\text { przedsiębiorstw zajmujących } \\
\text { się badaniami rynku }\end{array}$ & $\begin{array}{l}\text { Zarządzanie wiedzą jest } \\
\text { warunkiem przetrwania na } \\
\text { rynku }\end{array}$ & $\begin{array}{l}\text { Kapitał intelektualny } \\
\text { jest budowany w celu } \\
\text { gromadzenia i tworzenia } \\
\text { wiedzy oraz oferowania } \\
\text { wiedzy na rynku }\end{array}$ \\
\hline IV & $\begin{array}{l}\text { Zarządzanie wiedzą jako } \\
\text { sposób doskonalenia } \\
\text { procesów w firmach, } \\
\text { w których wewnętrzne } \\
\text { procesy są na tyle } \\
\text { skomplikowane, iż wymagają } \\
\text { ciągłego usprawniania }\end{array}$ & $\begin{array}{l}\text { Dotyczy to przedsiębiorstw } \\
\text { działających w bardzo } \\
\text { złożonych i zmiennych } \\
\text { sektorach, np. w branży } \\
\text { logistycznej }\end{array}$ & $\begin{array}{l}\text { Kapitał intelektualny służy } \\
\text { do doskonalenia procesów }\end{array}$ \\
\hline
\end{tabular}

Źródło: opracowanie własne na podstawie: A. Sopińska, P. Wachowiak (2006) 
M. Kozioł przedstawia pogląd, iż jedną z ważniejszych barier wewnętrznych rozwoju małego przedsiębiorstwa jest bariera edukacyjna (Kozioł, 2013). Wymienia on następujące czynniki związane z wiedzą, utrudniające rozwój firmy MŚP: słaba kultura przedsiębiorczości, słaba znajomość nowoczesnych metod zarządzania, ograniczony dostęp do informacji gospodarczej, brak umiejętności pozyskiwania, gromadzenia i wykorzystywania informacji z otoczenia, niski stopień wykorzystania Internetu i innych narzędzi IT, luki w potencjale kwalifikacyjnym spowodowane niskimi kwalifikacjami pracowników, wysoka fluktuacja pracowników, zwłaszcza specjalistów, niska zdolność i skłonność do uczenia się, brak systemu kształcenia w zakresie small business i inne (Wilmańska, 2010). W kontekście wielu wymiarów wiedzy niezbędnej w przedsiębiorstwie można wskazać na interdyscyplinarny charakter tego zasobu, obejmujący wiele kategorii i dziedzin, wśród których można wskazać następujące obszary:

- technika i technologia właściwe dla danej branży czy gałęzi przemysłu, w której funkcjonuje przedsiębiorstwo,

- ekonomia w zakresie niezbędnym do stosowania w przedsiębiorstwie,

- organizacja i zarządzanie jako umiejętność optymalnego planowania i realizowania działalności przedsiębiorstwa oraz stosowania odpowiednich instrumentów w tym zakresie,

- marketing - niezbędny do prawidłowego odczytywania sygnałów z rynku oraz podejmowania dialogu z klientami i innymi uczestnikami rynku,

- logistyka - jako specyficzny i unikalny obszar zastosowania wiedzy logistycznej do wspomagania zarządzania procesami w przedsiębiorstwie,

- informatyka i posługiwanie się techniką IT - w zakresie niezbędnym do prawidłowej komunikacji wewnątrz przedsiębiorstwa oraz pomiędzy firmą a otoczeniem oraz w zakresie wymaganym dla szeroko pojętego zarządzania przedsiębiorstwem.

\section{Obszary wiedzy logistycznej w przedsiębiorstwie}

Prawidłowe funkcjonowanie systemu logistycznego przedsiębiorstwa wymaga posiadania właściwych zasobów wiedzy we wszystkich obszarach procesów logistycznych. Wiedza ukryta, którą posiadają menedżerowie i szeregowi pracownicy, tworzy zespołowy potencjał, którego poziom zapewnia osiąganie oczekiwanych efektów. Znajomość procesów, ich struktury oraz przebiegu może stać się podstawą do identyfikowania problemów zakłócających realizację oraz w efekcie może prowadzić do ich doskonalenia. Porównując struktury systemów logistycznych w przedsiębiorstwach dużych oraz w firmach z sektora małych i średnich przedsiębiorstw, można dostrzec w nich indywidualny charakter systemów oraz ich ograniczone wzajemne relacje. W podobny sposób należy podejść do analizy infrastruktury logistycznej w przedsiębiorstwach MŚP (Janczewska, 2011). Współczesna logistyka odgrywa w przedsiębiorstwach istotna rolę i koncentruje się na przepływach towarów oraz informacji (Gołembska, 2010). Do najważniejszych kategorii procesów logistycznych można zaliczyć:

- procesy wspomagające przepływ fizyczny materiałów i towarów,

- procesy wspomagające przepływ informacji,

- procesy wspomagające logistyczną obsługę klientów.

W grupie procesów wspomagających przepływ fizyczny materiałów i usług występują procesy transportowe, magazynowe, przeładunkowe, sortowania towarów, pakowania 
i znakowania, procesy produkcji, procesy dystrybucji. Rozwój technologii wspiera procesy przepływu informacji przez możliwości wykorzystania Internetu, GPS-u oraz łączności satelitarnej. Logistyczna obsługa klientów wymaga z kolei posiłkowania się instrumentami marketingowymi w celu poprawy i doskonalenia kompleksowej obsługi klientów. Cechy charakterystyczne procesów logistycznych w przedsiębiorstwie można rozpatrywać wieloaspektowo, w zależności od przyjętych kryteriów (Dwiliński, 2006):

- ujęcie zasobowe: uwzględnia zasoby niezbędne do realizacji danego procesu,

- ujęcie funkcjonalne: dotyczy dostarczania zasobów do firmy oraz dostarczania wyrobów gotowych klientom,

- ujęcie efektywnościowe: zawiera wartościowanie rozwiązań logistycznych przy zastosowaniu oceny parametrów ekonomicznych, technicznych, jakościowych, społecznych, ekologicznym itp.

System logistyczny przedsiębiorstwa to celowo zorganizowany przepływ dóbr fizycznych i informacji. Jego elementami składowymi są poszczególne sfery działań logistycznych. Te sfery są ze sobą sprzężone, od siebie uzależnione i ze sobą powiązane. Jest systemem otwartym, ponieważ prowadzi wymianę materii ze swoim otoczeniem przez wejścia i wyjścia. W systemie logistycznym można zidentyfikować następujące procesy logistyczne: proces zaopatrzenia, proces magazynowania, proces produkcji, proces dystrybucji, procesy transportowe. Procesy logistyczne oraz powiązania pomiędzy nimi przedstawiono na rycinie 1. Można na niej wskazać kategorie powiązania poszczególnych procesów logistycznych wewnątrz przedsiębiorstwa oraz relacje $z$ otoczeniem firmy: $z$ dostawcami oraz pośrednio $\mathrm{z}$ nabywcami.

Ryc. 1. Procesy logistyczne w przedsiębiorstwie

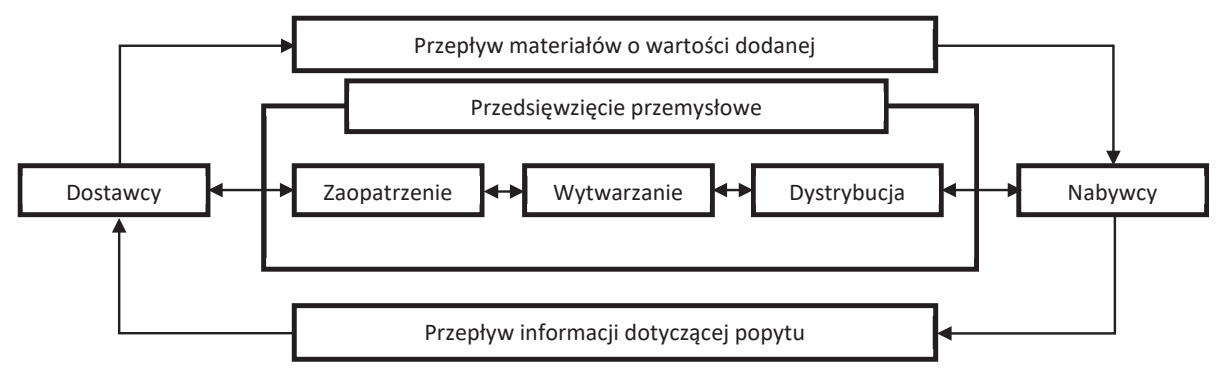

Źródo: Christopher (2000: 14)

Otoczenie systemu logistycznego przedsiębiorstwa tworzą zewnętrzne (nadrzędne) systemy wpływające na realizację danego procesu produkcji, takie jak system regulacji prawnych krajowych i zagranicznych, systemy finansowe, dostawcy, klienci, konkurenci oraz ważne zjawiska, takie jak globalizacja. Funkcjonowanie logistycznego przedsiębiorstwa wymaga zasilania w nowe informacje, technologie, procedury, umiejętności oraz ogólnie mówiąc - wiedzę niezbędną do realizacji procesów logistycznych.

Wyniki badań własnych

Przedmiotem badań własnych była identyfikacja wiedzy niezbędnej do prowadzenia procesów logistycznych w przedsiębiorstwie MŚP. Badania przeprowadzono w latach 
2015-2016 wśród 50 firm z województw: łódzkiego (20), mazowieckiego (20), kujawsko-pomorskiego (10). W przeprowadzeniu badania brali udział studenci ostatnich lat studiów magisterskich niestacjonarnych, na kierunku zarządzanie. Badanie typu case study poprzedzone było wykładem wprowadzającym. W badaniach ankietowych wykorzystano platformę e-learningową. Dobór próby był celowy, próba nie była reprezentatywna i wnioski z badań dotyczą wyłącznie badanej grupy przedsiębiorstw. Celem badania była identyfikacja elementów zasobów wiedzy w przedsiębiorstwach oraz relacje pomiędzy elementami.

W artykule przedstawiono wynik przykładowego badania typu case study przedsiębiorstwa $z$ branży cukierniczej3. Przedsiębiorstwo prowadzi działalność ponad 20 lat, głównym kierunkiem działalności jest produkcja wyrobów cukierniczych na zamówienie klientów zagranicznych. W dodatkowymi obszarami wiedzy badanymi w tym przedsiębiorstwie były zagadnienia związane z produkcją żywności, bezpieczeństwem żywności, technologią, know-how oraz recepturami itd. Elementy składowe zasobów wiedzy logistycznej przedstawiono w tabeli 2. Szczególny rodzaj wytwarzanych produktów wskazywał jednoznacznie obszar wiedzy niezbędnej do realizacji procesów logistycznych w przedsiębiorstwie, co zostało przedstawione w tabeli 2.

Tab. 2. Elementy wiedzy logistycznej w badanym przedsiębiorstwie - na podstawie badania typu case study

\begin{tabular}{|c|c|c|}
\hline Lp. & $\begin{array}{l}\text { Elementy wiedzy } \\
\text { logistycznej w badanym } \\
\text { przedsiębiorstwie }\end{array}$ & $\begin{array}{c}\text { Charakterystyka elementów wiedzy w badanym } \\
\text { przedsiębiorstwie MŚP }\end{array}$ \\
\hline 1. & $\begin{array}{l}\text { Wiedza o wartości } \\
\text { oferowanej klientowi }\end{array}$ & $\begin{array}{l}\text { Poszukiwanie wiedzy o kreowanych wartościach istotnych } \\
\text { dla klientów. Tworzenie wartości w mikroprzedsiębiorstwie } \\
\text { polega na sprawnym i efektywnym działaniu, terminowym } \\
\text { realizowaniu zamówień na eksport, dopasowaniu oferty } \\
\text { do indywidualnych wymagań klientów, np. zdrowa żywność, } \\
\text { niestosowanie polepszaczy i konserwantów, opakowania } \\
\text { zgodne z wymaganiami odbiorców zagranicznych }\end{array}$ \\
\hline 2. & $\begin{array}{l}\text { Wiedza o klientach, } \\
\text { segmentach rynku }\end{array}$ & $\begin{array}{l}\text { Firma adresuje swoją ofertę do następujących klientów: } \\
\text { - klienci zagraniczni kupujący wyroby cukiernicze } \\
\text { pod marką własną } \\
\text { - klienci zagraniczni kupujący wyroby pod marką } \\
\text { producenta } \\
\text { - klienci sieciowi wymagający najniższych cen }\end{array}$ \\
\hline 3. & $\begin{array}{l}\text { Wiedza o aktualnej ofercie } \\
\text { i możliwym poszerzeniu } \\
\text { zakresu oferty }\end{array}$ & $\begin{array}{l}\text { Szeroka i kompleksowa obsługa klienta: produkty } \\
\text { eksponowane w ofercie, na stronie internetowej, ekspozycje } \\
\text { na targach i wystawach, usługi dodatkowe, produkty } \\
\text { na indywidualne zamówienie (np. cukierki okazjonalne) } \\
\text { obsługa wirtualna }\end{array}$ \\
\hline 4. & $\begin{array}{l}\text { Wiedza o możliwości } \\
\text { kształtowania polityki } \\
\text { cenowej }\end{array}$ & $\begin{array}{l}\text { Przedsiębiorstwo negocjuje ceny z klientami zagranicznymi, } \\
\text { dla stałych klientów stosuje wydłużone terminy płatności, } \\
\text { dla nowych stosuje ceny promocyjne }\end{array}$ \\
\hline
\end{tabular}

${ }^{3} \mathrm{Na}$ podstawie informacji ze strony internetowej przedsiębiorstwa: http://www.majami.pl (data dostępu: 1 października 2017). 


\begin{tabular}{|c|c|c|}
\hline 5. & $\begin{array}{l}\text { Informacje o możliwych } \\
\text { źródłach przychodów } \\
\text { i wsparcia finansowego }\end{array}$ & $\begin{array}{l}\text { Produkcja i sprzedaż wyrobów; wsparcie finansowe } \\
\text { z funduszy unijnych, kredyt z banku dla przedsiębiorstwa, } \\
\text { dofinansowanie z funduszy specjalnych }\end{array}$ \\
\hline 6. & $\begin{array}{l}\text { Wiedza o działaniach oraz } \\
\text { relacjach } \mathrm{z} \text { otoczeniem }\end{array}$ & $\begin{array}{l}\text { Dopasowanie do wymagań i oczekiwań klienta, współpraca } \\
\text { z dostawcami surowców i materiałów, poszukiwanie wiedzy } \\
\text { o konkurentach }\end{array}$ \\
\hline 7. & $\begin{array}{l}\text { Wiedza pozyskiwana } \\
\text { w określonych celach } \\
\text { operacyjnych }\end{array}$ & $\begin{array}{l}\text { Oparta na własnej technologii i technice, recepturach, } \\
\text { procedurach oraz wiedzy pracowników; stosowanie internetu } \\
\text { w kontaktach oraz stosowanie marketingu zintegrowanego }\end{array}$ \\
\hline 8. & $\begin{array}{l}\text { Wiedza o indywidualnej } \\
\text { realizacji zamówień } \\
\text { klientów }\end{array}$ & $\begin{array}{l}\text { Realizacja ofert dostosowanych do indywidualnych potrzeb } \\
\text { klientów, wzbogacanie ofert o nowe, zgłaszane np. przez } \\
\text { indywidualnych klientów - m.in. produkty ekologiczne, } \\
\text { zdrowotne, bezcukrowe }\end{array}$ \\
\hline 9. & $\begin{array}{l}\text { Utrwalanie wiedzy, } \\
\text { tworzenie procedur działań } \\
\text { opartych na wiedzy }\end{array}$ & $\begin{array}{l}\text { Wysoka jakość usług oraz produktów, niezawodność, } \\
\text { gotowość do dopasowania usługi do potrzeb klientów, } \\
\text { zaufanie do firmy, dobre kontakty z klientem, dbałość } \\
\text { o klienta, budowanie indywidualnych relacji z klientami }\end{array}$ \\
\hline 10. & $\begin{array}{l}\text { Wiedza dotycząca } \\
\text { nowoczesnych procedur } \\
\text { zarządzania jakością }\end{array}$ & $\begin{array}{l}\text { Wdrażanie systemów zarządzania jakością; tworzenie } \\
\text { zapisów jakości, audytów jakości, doskonalenie systemu } \\
\text { zarządzania jakością }\end{array}$ \\
\hline
\end{tabular}

Źródło: opracowanie własne

W zależności od kategorii wielkości przedsiębiorstwa procesy logistyczne wymagać będą odrębnych zasobów, charakterystycznych dla danej kategorii, przy czym czynnikiem różnicującym poszczególne grupy przedsiębiorstw będzie nie tylko czynnik ilościowy, lecz także charakterystyka jakościowa zasobów oraz ich struktura.

\section{Model zarządzania wiedzą w działalności logistycznej MŚP na podstawie badań własnych}

Modelowe ujęcie zarządzania wiedzą w działalności logistycznej w badanych przedsiębiorstwach przedstawiono na rycinie 2 . Badanie potencjału intelektualnego wskazało na przewagę wiedzy wynikającej z doświadczenia nad wiedzą teoretyczną, co wpływało na konwersję wiedzy według modelu spirali wiedzy.

Zarządzanie wiedzą niezbędną do realizacji procesów logistycznych przejawia się w badanym przedsiębiorstwie przez:

- opracowywanie nowych innowacyjnych technologii i produktów oraz realizację procesów logistycznych,

- poszukiwanie nowych rynków zagranicznych,

- poszukiwanie nowych źródeł finansowania,

- wdrażanie nowych rozwiązań transportowych i informatycznych,

- poszukiwanie partnerów wśród jednostek sfery nauki w celu prowadzenia działalności B+R,

- pozyskiwanie wiedzy podczas szkoleń oraz ze współpracy z firmami zewnętrznymi. 
Ryc. 2. Model zarządzania wiedzą w działalności logistycznej na podstawie badania case study

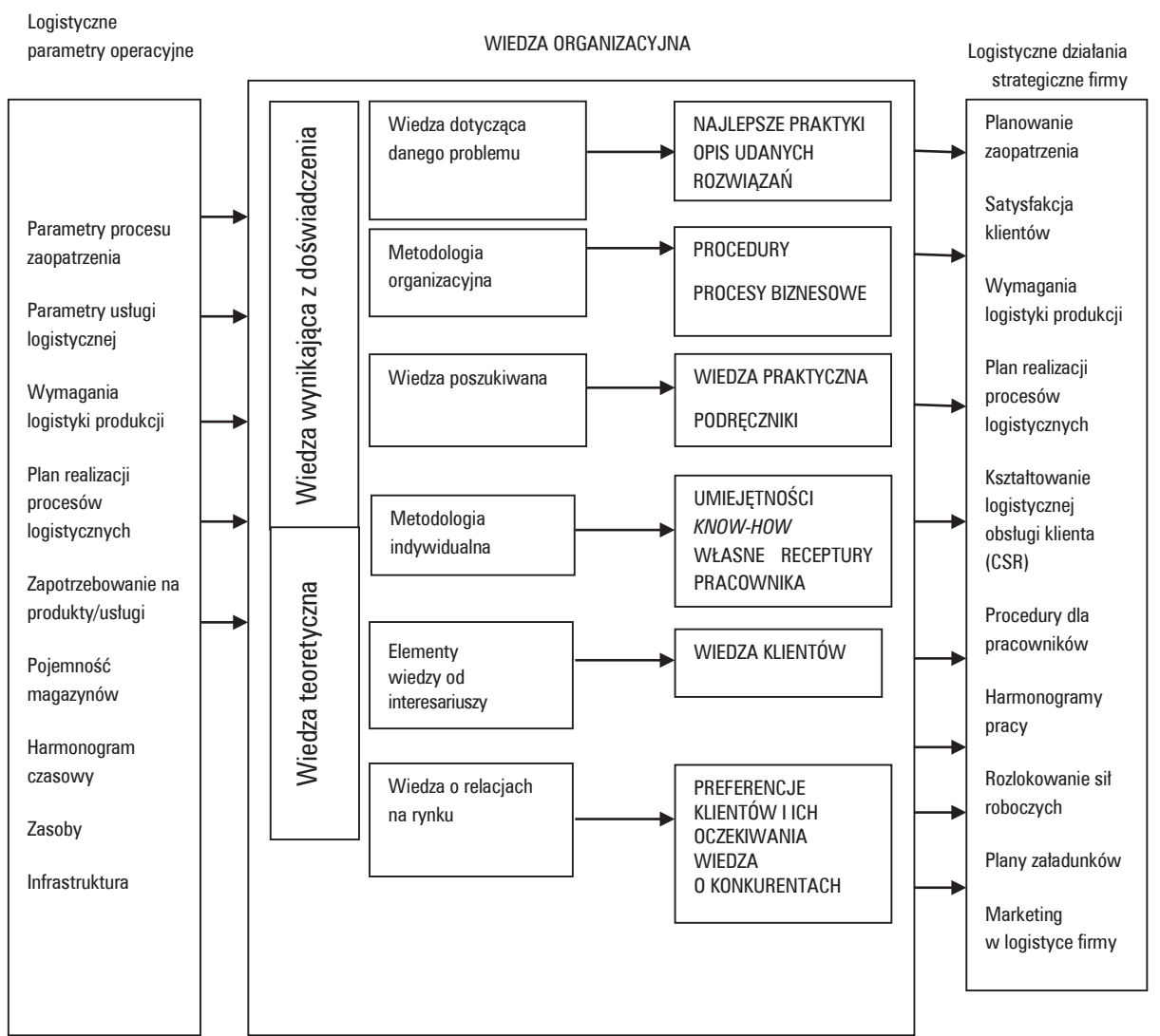

Źródło: opracowanie własne na podstawie badań oraz Chow i in. (2005)

\section{Wnioski z badań własnych}

W działalności logistycznej przedsiębiorstwa MŚP jest niezbędna wiedza na temat procesów logistycznych realizowanych w przedsiębiorstwie oraz wiedza specjalistyczna związana z gałęzią przemysłu, w której działa przedsiębiorstwo. Interdyscyplinarny charakter zarządzania logistycznego pozwala na integrowanie wiedzy niezbędnej w każdej fazie danego procesu logistycznego. Logistyczne procesy operacyjne opierają się głównie na zasobach wiedzy organizacyjnej, co wykazano w badaniach, podając przykłady efektów wykorzystania wiedzy organizacyjnej w kreowaniu działań logistycznych, takich jak planowanie procesów logistycznych, monitorowanie satysfakcji klientów, kształtowanie logistycznej obsługi klientów oraz wielu innych (patrz: ryc. 2). W badaniach pozyskano informacje na temat zasobów wiedzy oraz ich wykorzystania w procesach logistycznych, co objaśnia pierwsze pytanie badawcze.

Barierą w konwersji wiedzy według modelu spirali wiedzy był w badanych firmach brak wykształconej kadry. Potwierdziło to badanie potencjału intelektualnego, co pozwala na objaśnienie drugiego pytania badawczego. O ile duże przedsiębiorstwa zatrudniają 
menedżerów posiadających odpowiednie wykształcenie i doświadczenie, o tyle w firmach z sektora MŚP problematyką zarządzania logistycznego zajmuje się właściciel lub osoba przez niego wyznaczona.

\section{Podsumowanie}

Celem artykułu była prezentacja badań własnych prowadzonych w przedsiębiorstwach MŚP, a dotyczących procesu zarządzania wiedzą w działalności logistycznej. Sformułowano dwa problemy badawcze, które przeanalizowano na podstawie badań. Zaproponowano własny model zarządzania wiedzą w działalności logistycznej w badanych przedsiębiorstwach. Wnioski i uogólnienia odnoszą się wyłącznie do badanej próby. Na podstawie wyników badań sformułowano założenia do modelu zarządzania wiedzą w działalności logistycznej w badanych przedsiębiorstwach. Model łączy wiedzę logistyczną z wiedzą organizacyjną - wewnętrzną przedsiębiorstwa. Wskazane byłoby prowadzenie dalszych badań w kierunku zarządzania wiedzą w sektorze małych i średnich przedsiębiorstw.

Literatura

References

Baruk, J. (2006). Zarzadzanie wiedza i innowacjami. Toruń: Wydawnictwo Adam Marszałek.

Błaszczuk, A. (2004). Korzyści z zarządzania wiedzą. W: A. Brdulak, J.J. Brdulak, M. Guzik, A. Pawluczuk, Zarządzanie wiedzą w polskich przedsiębiorstwach. Warszawa: Wydawnictwo Szkoły Głównej Handlowej.

Chow, H.K.H., Choy, K.L., Lee, K.L., Chan, F.T.S., Felix T.S. (2005). Design of a knowledge- based logistics strategy system. Expert System with Applications 29(2005), 272-279.

Christopher, M. (2000). Logistyka i zarządzanie łańcuchem dostaw. Warszawa: Wydawnictwo Polskie Centrum Doradztwa Logistycznego.

Drucker, P.F. (1999). Pokapitalistyczne społeczeństwo. Warszawa: Wydawnictwo Naukowe PWN.

Dwiliński, L. (2006). Zarys logistyki przedsiębiorstwa. Warszawa: Oficyna Wydawnicza Politechniki Warszawskiej.

Gierszewska, G. (2011). Zarządzanie wiedza w przedsiębiorstwie. Warszawa: Oficyna Wydawnicza Politechniki Warszawskiej.

Gołembska, E. (2010). Logistyka jako zarządzanie łańcuchem dostaw. Poznań: Wydawnictwo Akademii Ekonomicznej w Poznaniu.

Kordel, P. i in. (2010). Inteligentne organizacje - zarządzanie wiedza i kompetencjami pracowników. Warszawa: PARP.

Janczewska, D. (2011). Uwarunkowania procesów logistycznych w sektorze mikro przedsiębiorstw. W: Zarzadzanie innowacyjne w gospodarce i biznesie, t. XI, nr 13, 131-149.

Kozioł, M. (2013). Wykorzystanie e-learningu w procesie szkolenia pracowników małych i średnich przedsiębiorstw. Zeszyty Naukowe Małopolskiej Wyższej Szkoły Ekonomicznej w Tarnowie, 22(1), 47, 45-57.

Nonaka, I., Takeuchi,H.(1995). The Knowledge Creating Company. Oxford: Oxford University Press.

Porter, M.E. (2001). Porter o konkurencji. Warszawa: PWE.

Rozwój kadr Tubądzin Management Group Sp. z o.o. Pozyskano z: http://www.tubadzin.pl/projekty-efs

Strojny, M. (2000). Zarządzanie wiedzą. Ogólny zarys koncepcji. Przegląd Organizacji, 2, 21-25.

Toffler, A., Toffler, H. (1999). Budowanie nowej cywilizacji. Polityka trzeciej fali. Poznań: Zysk i S-ka.

Senge, P. (2012). Piąta dyscyplina. Warszawa: PWN. 
Sopińska, A., Wachowiak, P. (2006). Modele zarządzania wiedzą w przedsiębiorstwie. E-mentor, 1(14). Pozyskano z: http://www.e-mentor.edu.pl/artykul/index/numer/14/id/275

Teece, D.J. (1998). Capturing Value from Knowledge Assets: The New Economy, Markets fo KnowHow, and Intangible Assets. California Review Management, 40(3).

Wilmańska, A. (red.). (2010). Raport o stanie malych i średnich przedsiębiorstw w Polsce w latach 20082009. Warszawa: Polska Agencja Rozwoju Przedsiębiorczości.

Wojnicka, E. (2011). Popytowe podejście do innowacji - charakterystyka koncepcji. Materiały z Konferencji „Innowacje w sektorze usług” PARP, 3.03.2011. Warszawa.

Danuta Janczewska, dr inż., adiunkt w Katedrze E-Gospodarki, na Wydziale Zarządzania Społecznej Akademii Nauk w Łodzi. Zainteresowania naukowe związane z problematyką różnorodnych aspektów zarządzania w sektorze mikroprzedsiębiorstw, nowoczesnymi technikami i metodami zarządzania w sektorze. Posiada ponad 130 publikacji krajowych i zagranicznych, uczestniczyła w konferencjach krajowych i międzynarodowych na temat przedsiębiorczości i zarządzania w sektorze mikroprzedsiębiorstw. Badania własne nad metodami zarządzania wiedzą w przedsiębiorstwach MŚP, w tym w mikroprzedsiębiorstwach, prowadzi od roku 2004.

Danuta Janczewska, DSc, senior lecturer in the Faculty of Management at the University of Social Sciences in Lódź, in the Department of E-Economy. Research interests are connected to management in micro enterprises, the modern methods of management in micro enterprises. The author of over 130 articles and papers in national and foreign journals and participant of numerous conferences. She has conducted own research on SMEs, including management of micro enterprises since 2004 .

\section{Adres/Address:}

Społeczna Akademia Nauk w Łodzi

ul. Sienkiewicza 9

90-113 Łódź, Polska

e-mail: djanczewska@spoleczna.pl 